\title{
ADSORPSI-DESORPSI ZAT WARNA AZO JENIS REMAZOL BLACK B MENGGUNAKAN MEMBRAN POLIELEKTROLIT (PEC) KITOSAN-PEKTIN
}

\author{
Ni Putu Sri Ayuni ${ }^{1}$, Ni Wayan Yuningrat ${ }^{2}$, Ketut Yesi Andriani ${ }^{3}$ \\ 1,2,3 Jurusan Analis Kimia, Fakultas Matematika dan IImu Pengetahuan Alam, \\ Universitas Pendidikan Ganesha, \\ Singaraja-Bali, Indonesia \\ e-mail: nps.ayuni@gmail.com
}

\begin{abstract}
Abstrak
Sekitar $2-50 \%$ dari zat warna azo yang digunakan selama proses pencelupan ini tidak mengikat serat dan langsung dilepaskan ke lingkungan melalui instalasi pengolahan limbah. $\mathrm{Hal}$ ini perlu dilakukan pengolahan limbah cair yang mengandung zat warna azo jenis Remazol Black B sebelum dibuang ke lingkungan. Penelitian ini bertujuan untuk mengetahui kondisi optimum membran PEC kitosan-pektin yang dapat digunakan untuk mengadsorpsi zat warna azo jenis Remazol Black B .Untuk memperoleh kondisi optimum akan dilakukan adsorpsi zat warna azo jenis Remazol Black B dengan variasi waktu kontak (5-150 menit), $\mathrm{pH}(5-9)$ dan konsentrasi larutan zat warna azo jenis Remazol Black B $(5,10,15,20$, dan 25 $\mathrm{mg} / \mathrm{L}$ ). Untuk mengetahui karakteristik zat warna jenis Remazol Black B oleh membran PEC kitosan-pektin di analisis dengan persamaan isoterm adsorpsi Langmuir dan isoterm adsorpsi Freundlich sedangkan daya adsorpsi maksimum dari membran PEC kitosan pektin ditentukan dari kurva berdasarkan karakteristik membran yang diperoleh. Hasil penelitian menunjukkan bahwa adsorpsi zat warna azo jenis Remazol Black B terjadi pada kondisi optimum dengan $\mathrm{pH}$ 5, waktu 120 menit dan konsentrasi larutan zat warna azo jenis Remazol Black B $10 \mathrm{mg} / \mathrm{L}(62,75 \%)$. Pola adsorpsi mengikuti pola adsorpsi isoterm Freundlich dengan daya adsorpsi maksimum 0,02 (mg/g). Untuk efisiensi desorpsi maksimal diperoleh pada larutan $\mathrm{NaCl} 1 \mathrm{M}(11,17 \%)$
\end{abstract}

Kata Kunci: adsorpsi, membran polielektrolit kitosan pektin, Remazol Black B

\begin{abstract}
Azo dyes produced approximately $2-50 \%$ from dying process were thrown through effluent to the environment without any treatment. The objective of this research were to know the optimum condition of PEC chitosan pectin membrane using to adsorp Remazol Black $B$ with various contact time (5-150 min), $\mathrm{pH}(5-9)$ and Remazol Black B concentration (5, 10, 15, 20, dan $25 \mathrm{mg} / \mathrm{L}$ ). Adsorption charactheristic of Remazol Black B by PEC chitosan pectin membrane were determined by Langmuir and Freundlich isotherm equation. Maximum capacity adsorption was determined by the graph of membrane characteristic. The results show that optimum condition of Remazol Black $B$ adsorption by PEC chitosan pectin membrane at $\mathrm{pH} 5,10 \mathrm{mg} / \mathrm{L}$ remazol black B for 120 minutes $(62,75 \%)$. The adsorption pattern is Freundlich isoterm with maximum capacity $0,02(\mathrm{mg} / \mathrm{g})$.Maximal Desorption efisiency at $\mathrm{NaCl} 1 \mathrm{M}(11,17 \%)$
\end{abstract}

Keywords : adsorption, PEC chitosan pectin membrane, Remazol Black B 


\section{PENDAHULUAN}

Perkembangan industri tekstil di Indonesia yang semakin pesat tidak hanya memberikan manfaat namun juga menimbulkan dampak negatif bagi lingkungan. Hal ini dikarenakan dalam produksinya industri tekstil selalu menghasilkan limbah yaitu limbah zat warna. Limbah zat warna yang dihasilkan merupakan senyawa organik yang bersifat sulit terdegradasi, resisten, dan toksik. Limbah zat warna ini apabila dibuang ke dalam perairan akan menyebabkan pencemaran lingkungan.

Salah satu zat warna yang digunakan pada industri tekstil adalah zat warna azo jenis Remazol Black B (Erkurt, 2010). Penggunaan zat warna azo paling banyak digunakan untuk mewarnai produk tekstil karena harganya ekonomis dan mudah diperoleh (Bafana etal.,2008). Diperkirakan sekitar $2-50 \%$ dari zat warna azo yang digunakan selama proses pencelupan dalam industri tekstil tidak mengikat serat sehingga zat warna tersebut dilepaskan ke lingkungan melalui instalasi pengolahan limbah (Reisch, 1996). Secara khusus, pewarna reaktif yang larut digunakan untuk meningkatkan kuantitas hidrolisis selama aplikasi tanpa fiksasi yang lengkap. Akibatnya, sebagian besar pewarna ini dilepaskan ke lingkungan tanah dan air. Senyawa pewarna ini mempertahankan warna dan integritas struktural di bawah paparan sinar matahari, reaksi kimia (Guelli et al., 2008) dan juga menunjukkan resistensi yang tinggi terhadap degradasi mikroba dalam sistem pengolahan air limbah. Hal ini dapat menyebabkan kontaminasi yang tinggi pada sungai dan air tanah di daerah-daerah yang memiliki banyak unit industri tekstil (Gong etal., 2005).
Keberadaan zat warna azo dalam perairan dapat menyebabkan terganggunya aktivitas fotosintesis dan fitoplankton karena tereduksinya sinar matahari yang masuk akibat dari perairan yang berwarna. Selain itu, juga terjadi perubahan $\mathrm{pH}$ dan meningkatnya nilai BOD dan COD perairan (Kannan et al. 2013). Oleh karena itu perlu dilakukan pengolahan limbah cair yang mengandung zat warna azo jenis Remazol Black $B$ sebelum dibuang ke lingkungan.

Untuk mengatasi masalah di atas diperlukan usaha untuk mengolah limbah cair yang efektif dan efisien dalam menurunkan polutan organik dan zat warna (Renita dkk.,2004). Berbagai cara telah dilakukan untuk pengolahan zat warna jenis Remazol Black $B$ antara lain dekolorisasi menggunakan jamur (Khalid, 2011) dan isolat bakteri (Kannan et al., 2013; Shah, 2014). Metode-metode tersebut memerlukan waktu yang lama, ketelitian yang tinggi serta biaya yang mahal.

Alternatif lain yang dapat digunakan untuk menghilangkan zat warna adalah adsorpsi menggunakan membran. Perkembangan teknologi membran sebagai unit pengolah limbah saat ini sangat pesat dan banyak digunakan. Operasi membran dapat diartikan sebagai proses pemisahan dua atau lebih komponen dari aliran fluida melalui suatu membran (Mulder, 1996). Proses adsorpsi zat warna oleh membran dipengaruhi oleh $\mathrm{pH}$ larutan dan waktu kontak. pH larutan akan berpengaruh terhadap jumlah interaksi dipol-dipol yang terdaji antara membran dan zat warna sedangkan waktu kontak menunjukkan kesetimbangan laju reaksi adsorpsi yaitu laju tertutupnya permukaan membran oleh adsorbat.

Dalam aplikasinya untuk proses pemisahan, pemurnian dan pemekatan, 
teknologi membran mempunyai berbagai keunggulan dibandingkan metoda pemisahan yang konvensional, di antaranya proses dapat dilakukan secara kontinyu, tidak memerlukan zat kimia tambahan, konsumsi energi rendah, pemisahan dapat dilakukan pada kondisi yang mudah diciptakan, dapat dilangsungkan pada temperatur rendah sehingga dapat digunakan untuk pemisahan senyawa yang tidak tahan temperatur tinggi, mudah dalam scale up, tidak membutuhkan kondisi yang ekstrim ( $\mathrm{pH}$ dan temperatur), material membran bervariasi sehingga mudah diadaptasikan pemakaiannya dan mudah dikombinasikan dengan proses pemisahan lainnya (Nirmasari, tt)

Salah satu bahan yang sering digunakan untuk pembuatan membran adalah kitosan. Kitosan merupakan polisakarida alam melimpah kedua setelah selulosa. Kitosan larut dalam asam, dan memiliki gugus amina sehingga bersifat sebagai polikation. Pektin merupakan polisakarida alam yang larut dalam air dan memiliki gugus karboksil termetilasi (Chen, 2010). Gugus karboksil dari pektin menyebabkan pektin dapat bertindak sebagai polianion dan bereaksi dengan kitosan yang bertindak sebagai polikation membentuk membran PEC.

Chen dkk.(2010) berhasil mensintesis membran PEC kitosan-pektin dan diperoleh hasil uji tarik membran PEC yang nilainya empat kali lebih besar daripada kitosan murni. Paduan kitosan dan pektin ini juga dilakukan untuk memperbaiki sifat mekanik dari masing-masing polimer. Membran PEC kitosan-pektin juga telah digunakan untuk transport kreatinin (Ayuni, 2013), urea (Asbanu, 2013), dan metilen biru (Tuny, 2013). Dilaporkan oleh mereka bahwa pada variasi perbandingan konsentrasi membran
PEC kitosan-pektin (70:30), (80,20), dan (90:10), diperoleh transpor terbaik untuk perbandingan kitosan dan pektin (70:30) dengan hasil kreatinin sebesar 25,24\%, urea sebesar 42,32\%, dan kapasitas adsorpsi maksimum metilen biru sebesar $112 \mathrm{mg} / \mathrm{g}$.

Berdasarkan keunggulan membran PEC-kitosan-pektin maka peneliti memandang perlu dilakukan pengkajian adsorpsi-desorpsi zat warna jenis Remazol Black B menggunakan membran PEC kitosan-pektin yang belum pernah dilakukan oleh orang lain sampai saat ini. Selain dilakukan adsorpsi Remazol Black B pada penelitian ini, juga akan dilakukan desorpsi terhadap Remazol Black B yangbertujuan untuk mengetahui kemampuan pelepasan zat warna jenis Remazol Black B pada akuades dan $\mathrm{NaCl}$ sehingga dapat diketahui regenerasi dari membran PEC kitosanpektin.

\section{METODE}

Bahan-bahan yang digunakan dalam penelitian ini adalah kitosan, pektin, akuades. $\mathrm{CH}_{3} \mathrm{COOH}, \mathrm{NaOH}$, zat warna azo jenis Remazol Black $B$, HCL. Bahan-bahan kimia tersebut memiliki kualitas pro analisis (p.a) yang berasal dari Merck.

Alat-alat yang digunakan dalam penelitian ini adalah $\mathrm{pH}$ meter, pengaduk magnet, neraca analitik, termometer, cawan petri, oven, shaker, alat penunjang berupa alat-alat gelas dan plastik, spektrofotometer UV-Vis.

Untuk pembuatan membran PEC kitosan-pektin (70:30); 0,03 g pektin dilarutkan dalam $4 \mathrm{~mL}$ akuades. Larutan pektin ditambahkan 0,07 g kitosan sambil diaduk dengan pengaduk magnet kemudian ditambahkan $16 \quad \mathrm{~mL} \quad \mathrm{CH}_{3} \mathrm{COOH} \quad 0,4 \mathrm{M}$. Larutan membran yang homogen dipipet sebanyak $10 \mathrm{~mL}$ dan dicetak dalam cawan 
petri. Larutan diuapkan dalam oven pada temperatur $70{ }^{\circ} \mathrm{C}$. Membran dalam cawan petri yang telah kering direndam dengan $\mathrm{NaOH} 1 \mathrm{M}$. Membran dilepaskan dari cawan petri kemudian dicuci dengan akuades.

Membran PEC kitosan-pektin dengan perbandingan 70:30 masing-masing dimasukkan ke dalam $30 \mathrm{~mL}$ zat warna azo jenis Remazol Black B 25 mg/L dan dikocok dengan variasi waktu $5,10,15,20,30,40$, 50, 60, 90, 120, dan 150 menit Setelah itu membran dipisahkan dari larutan dan dikeringkan, larutan zat warna azo jenis Remazol Black B yang tersisa diukur konsentrasinya dengan menggunakan spektrofotometer UV-Vis pada panjang gelombang maksimum.

Membran PEC kitosan-pektin dengan perbandingan 70:30 sebanyak 0,04 g dimasukkan ke dalam $30 \mathrm{~mL}$ zat warna azo jenis Remazol Black B 30 mg/L dengan variasi $\mathrm{pH}: 5,6,7,8,9$ dan dikocok selama waktu optimum. Selanjutnya membran dipisahkan dari larutan zat warna azo jenis Remazol Black B dan dikeringkan. Larutan zat warna azo jenis Remazol Black B yang tersisa diukur konsentrasinya dengan menggunakan spektrofotometer UV-Vis pada panjang gelombang maksimum.

Membran PEC kitosan-pektin dengan perbandingan 70:30 dimasukkan ke dalam $30 \mathrm{~mL}$ larutan zat warna azo jenis Remazol Black B dengan konsentrasi 5, 10, 15, 20, dan $25 \mathrm{mg} / \mathrm{L}$ pada $\mathrm{pH}$ dan waktu kontak optimum yang diperoleh. Selanjutnya membran dipisahkan dari larutan zat warna azo jenis Remazol Black B. Larutan zat warna azo jenis Remazol Black B yang tersisa diukur konsentrasinya dengan menggunakan spektrofotometer UV-Vis pada panjang gelombang maksimum.

Proses desorpsi diamati dengan menggunakan $\mathrm{NaCl} 1 \mathrm{M} ; 0,1 \mathrm{M}$ dan akuades. Membran hasil adsorpsi (pada kondisi optimum) yang telah kering ditambahkan dengan $\mathrm{NaCl} 1 \mathrm{M}$ dan $0,1 \mathrm{M}$ sebanyak $30 \mathrm{~mL}$, masing-masing diaduk selama 30, 60, 90 dan 120 menit. Larutan zat warna azo jenis Remazol Black B yang tersisa diukur konsentrasinya dengan menggunakan spektrofotometer UV-Vis pada panjang gelombang maksimum.

Dari pengukuran dengan menggunakan spektrofotometer UV-Vis diperoleh data absorbansi dan konsentrasi zat warna azo jenis Remazol Black $B$ sisa. Dari data tersebut dapat dihitung konsentrasi yang teradsorpsi dan efisiensi adsorpsi dari variasi konsentrasi zat warna azo jenis Remazol Black $B$ kemudian di analisis deskriptif. Efisiensi adsorpsi zat warna azo jenis Remazol Black $B$ dengan variasi waktu kontak, $\mathrm{pH}$ dan konsentrasi larutan dihitung dengan menggunakan Persamaan 1 :

$$
\% E=\frac{\left(C_{o}-C_{s t}\right)}{C_{o}} \times 100 \%
$$

dengan $\mathrm{C}_{0}=$ konsentrasi Remazol Black $B$ sebelum adsorpsi; $\mathrm{C}_{\text {st }}=$ konsentrasi Remazol Black $B$ setelah adsorpsi; dan

$\mathrm{E}=$ efisiensi. Untuk mengetahui karakteristik adsorpsi zat warna azo jenis Remazol Black $B$ oleh membran PEC kitosan-pektin dilakukan uji pola isoterm Langmuir dengan menggunakan persamaan 2 :

$$
\frac{\mathrm{C}}{\mathrm{x} / \mathrm{m}}=\frac{1}{\left(\frac{\mathrm{x}}{\mathrm{m}}\right) \mathrm{maks}^{\mathrm{k}}}+\frac{1}{\left(\frac{\mathrm{x}}{\mathrm{m}}\right) \mathrm{maks}} \mathrm{C}_{\mathrm{st}}
$$

Banyaknya zat yang teradsorpsi per massa membran adsorben ditentukan dengan persamaan 3 :

$\frac{\mathrm{x}}{\mathrm{m}}=\frac{\left(\mathrm{C}_{\mathrm{o}}-\mathrm{C}_{\mathrm{st}}\right) \times \mathrm{V}}{10^{6} \mathrm{~m} \cdot \mathrm{a}}$

$\mathrm{V}$ merupakan volume adsorbat yang digunakan, m.a adalah massa adsorben. 
Untuk uji pola isoterm Freundlich digunakan persamaan (4):

$\log (x / m)=\log k+1 / n \log C$

sedangkan daya adsorpsi maksimum ditentukan dengan membuat kurva berdasarkan karakterisasi adsorpsi yang diperoleh.

\section{HASIL DAN PEMBAHASAN}

Untuk mengetahui telah terjadinya interaksi dan kebenaran struktur antara kitosan dan pektin maka dilakukan analisis dengan spektrofotometer IR terhadap hasil sintesis. Spektra IR disajikan pada Gambar 1 sedangkan interpretasi untuk masingmasing bilangan gelombang disajikan pada tabel 1.

Tabel 1. Interpretasi Spektra IR

\begin{tabular}{cccc}
\hline $\begin{array}{c}\text { Bilangan } \\
\text { gelombang }\left(\mathrm{cm}^{-}\right.\end{array}$ & Kitosan & $\begin{array}{c}\text { Interpretasi } \\
\text { Pektin }\end{array}$ & PEC \\
\hline 1658 & $-\mathrm{C}=\mathrm{O}$ & & \\
1597 & $-\mathrm{N}-\mathrm{H}$ & $-\mathrm{C}=\mathrm{O}$ & \\
1743 & & Gugus karboksil & \\
1635 & & & Ikatan amida \\
1604 & & & \\
\hline
\end{tabular}

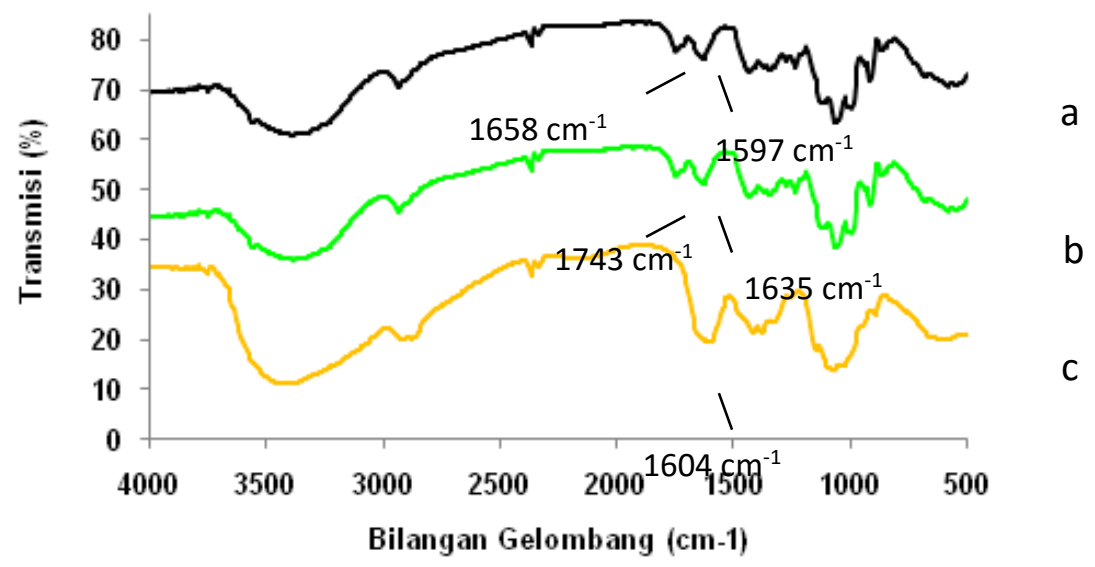

Gambar 1 Spektrum FTIR dari (a) Kitosan (b) Pektin (c) PEC kitosan-pektin

Membran PEC disintesis dari pengadukan kitosan dalam asam asetat dan pektin dalam akuades. Dalam suasana asam kitosan akan membentuk polikation sedangkan pektin jika dilarutkan dalam akubides membentuk polianion. Polikation dan polianion akan bereaksi membentuk polielektrolit melalui interaksi ionik. Skema pembentukan PEC untuk kitosan dan pektin (Bernabe dkk., 2005). 
Dari Tabel 1 dapat dilihat bahwa untuk kitosan, puncak $1658 \mathrm{~cm}^{-1}$ merupakan ikatan $-\mathrm{C}=\mathrm{O}$ dari gugus asetil dan puncak 1597 $\mathrm{cm}^{-1}$ merupakan ikatan $-\mathrm{N}-\mathrm{H}$ dari gugus amino. Pada pektin muncul puncak pada bilangan gelombang $1743 \mathrm{~cm}^{-1}$ merupakan ikatan $-\mathrm{C}=\mathrm{O}$ dari gugus karboksil termetoksilasi sedangkan puncak $1635 \mathrm{~cm}^{-1}$ merupakan gugus karboksil. Bilangan gelombang $1604 \mathrm{~cm}^{-1}$ diduga merupakan hasil interaksi ionik gugus karboksil (pektin) dan gugus amino yang membentuk PEC, hal ini sesuai dengan hasil sintesis membran PEC kitosan pektin dari Chen dkk. (2010).

Berdasarkan interpretasi spektra IR tersebut, maka membran PEC kitosan pektin telah berhasil di sintesis. Dari hasil interpretasi spektra IR struktur hipotetik membran PEC kitosan-pektin disajikan pada Gambar 2.

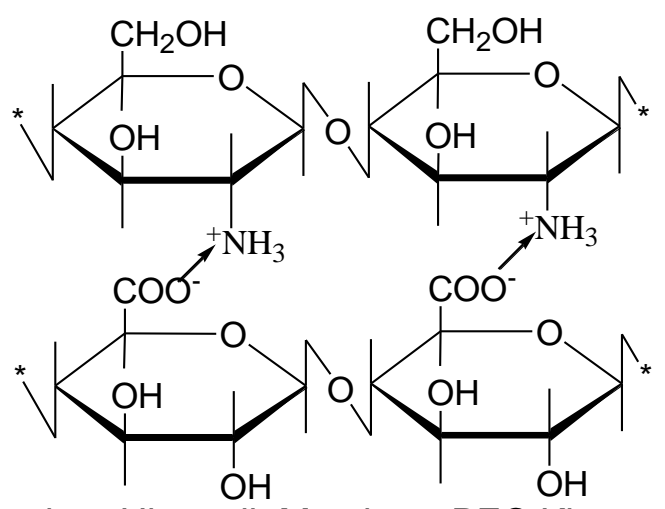

Gambar 2. Struktur Hipotetik Membran PEC Kitosan-Pektin

Zat warna azo jenis Remazol Black B yang diadsorpsi menggunakan membran PEC kitosan-pektin dengan variasi waktu kontak dari 5-150 menit diperoleh grafik seperti yang disajikan pada Gambar 3 . Berdasarkan Gambar 3 diperoleh hasil bahwa waktu kontak mempengaruhi proses adsorpsi zat warna azo jenis Remazol Black B. Efisiensi adsorpsi pada menit ke 5 sampai 120 menit naik secara signifikan. Hal ini disebabkan situs aktif pada membran masih banyak tersedia. Namun pada menit ke 150 efisiensi adsorpsi menurun karena situs aktif membran sudah terisi penuh sehingga pertambahan waktu kontak tidak lagi meningkatkan efisiensi adsorpsi. Menurut Silvi (2013) penurunan persen adsorpsi yang terjadi bisa disebabkan tidak semua adsorbat yang terikat pada membran merupakan ikatan elektrostatik sehingga memungkinkan adsorpsi fisika terjadi maka bisa terjadi pelepasan kembali pada waktu yang cukup lama pada adsorben yang telah jenuh. 


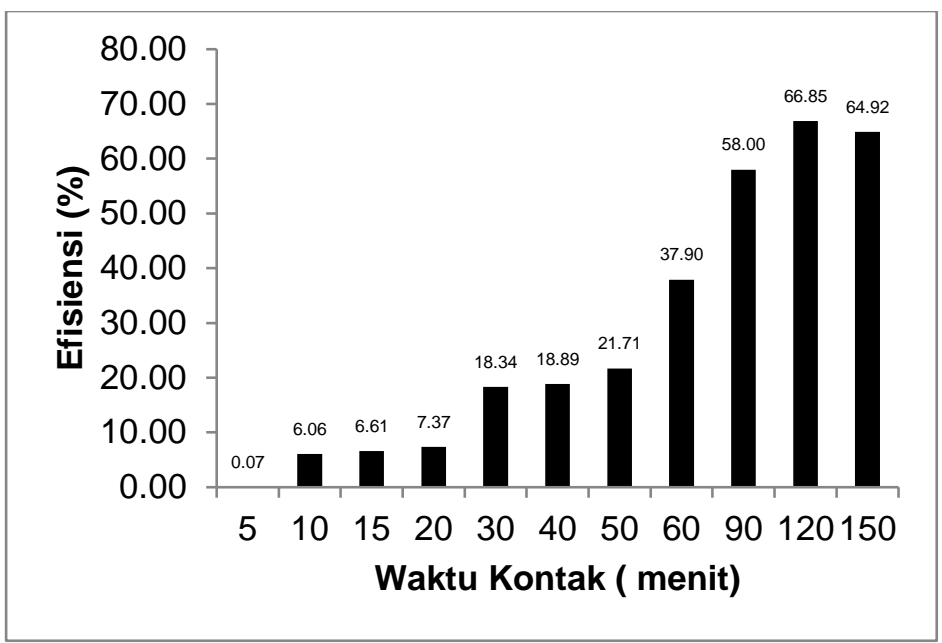

Gambar 3. Grafik hubungan waktu kontak dan efisiensi adsorpsi

Pengaruh pH larutan zat warna azo jenis Remazol Black B pada proses adsorpsi dipelajari mulai $\mathrm{pH}$ 5-9. Pada $\mathrm{pH}$ dibawah 5 dan diatas 9 , membran mengalami kerusakan. Dari Gambar 4 terlihat jumlah zat warna azo jenis Remazol Black B menghasilkan efisiensi adsorpsi maksimum pada $\mathrm{pH}$ 5. Hasil penelitian ini juga diperkuat oleh penelitian dari Anbalagan (2004) bahwa tingginya proses adsorpsi pada $\mathrm{pH}$ asam dikarenakan meningkatnya protonasi oleh penetralan muatan negatif dari permukan adsorben.

Pengaruh konsentrasi larutan zat warna azo jenis Remazol Black B dilakukan dengan variasi larutan 5, 10, 15, 20, dan 25 $\mathrm{mg} / \mathrm{L}$. Pada konsentrasi $10 \mathrm{mg} / \mathrm{L}$ diperoleh efisiensi adsorpsi maksimum (Gambar 5). Pada konsentrasi lebih besar dari $10 \mathrm{mg} / \mathrm{L}$ efisiensi mulai menurun karena jumlah zat warna azo jenis Remazol Black B dalam larutan semakin banyak sedangkan jumlah situs aktif yang tersedia tetap.

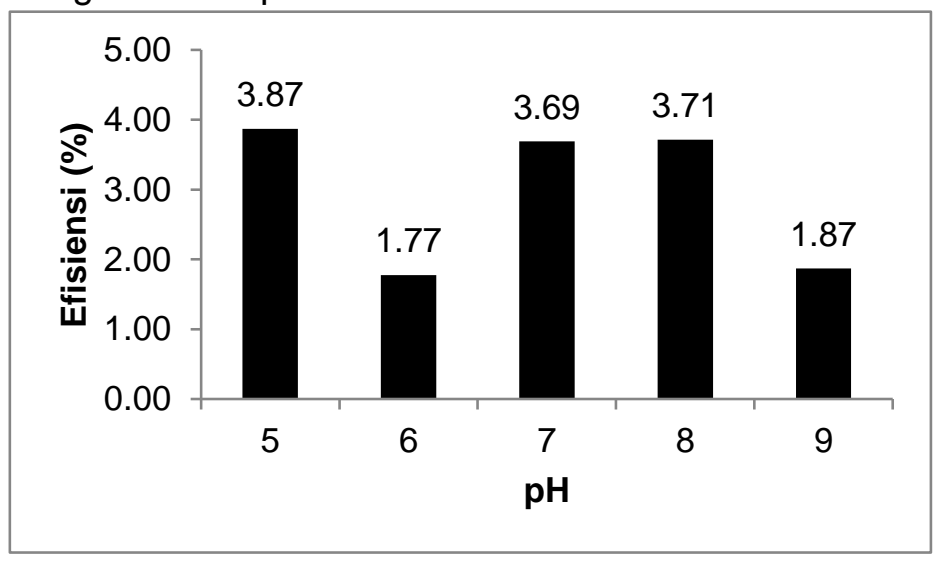

Gambar 4. Grafik hubungan $\mathrm{pH}$ dan efisiensi adsorpsi 


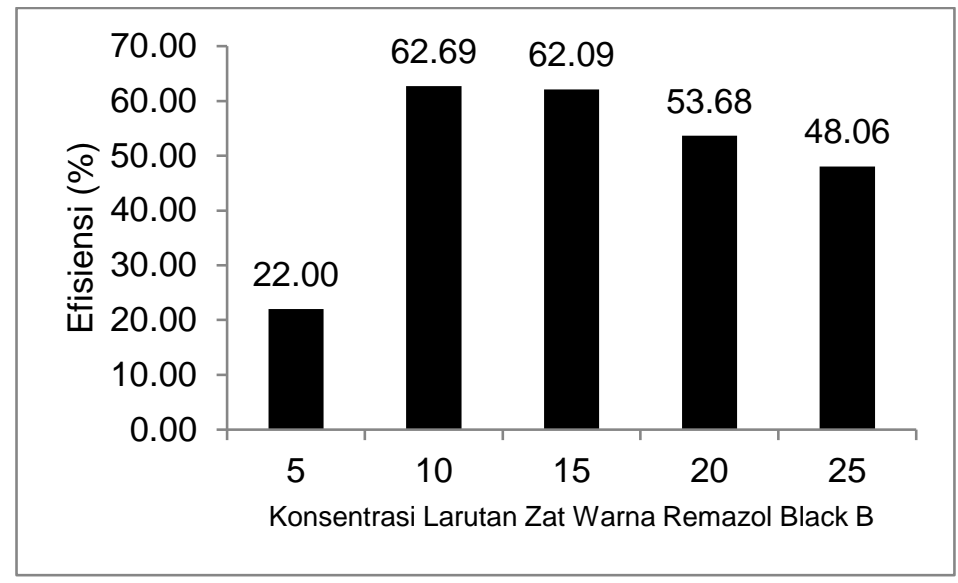

Gambar 5. Grafik hubungan konsentrasi Zat Warna Remazol Black B dan efisiensi adsorpsi

Tipe isoterm adsorpsi dapat digunakan untuk mempelajari mekanisme adsorpsi zat warna azo jenis Remazol Black B. Kapasitas adsorpsi dipelajari melalui tipe isotermnya. Telah banyak isoterm adsorpsi yang dikembangkan untuk mendeskripsikan interaksi antara adsorben dan adsorbat. Isoterm Freundlich dan Langmuir pada umumnya dianut oleh adsorpsi padat-cair (Anbalagan, 2004). Kurva regresi linier untuk tipe isoterm Freundlich dan Langmuir menggunakan data konsentrasi zat warna azo jenis Remazol Black B, konsentrasi teradsorpsi, dan bobot adsorben.

Isoterm adsorpsi zat warna azo jenis Remazol Black B oleh membran PEC kitosan pektin tipe Langmuir dan Freundlich disajikan pada Gambar 6 dan 7. Hasil penelitian menunjukkan bahwa semua kurva adalah linier. Hal ini disebabkan oleh banyaknya gugus kimia yang reaktif pada permukaan adsorben dan dapat mendukung terjadinya proses adsorpsi.

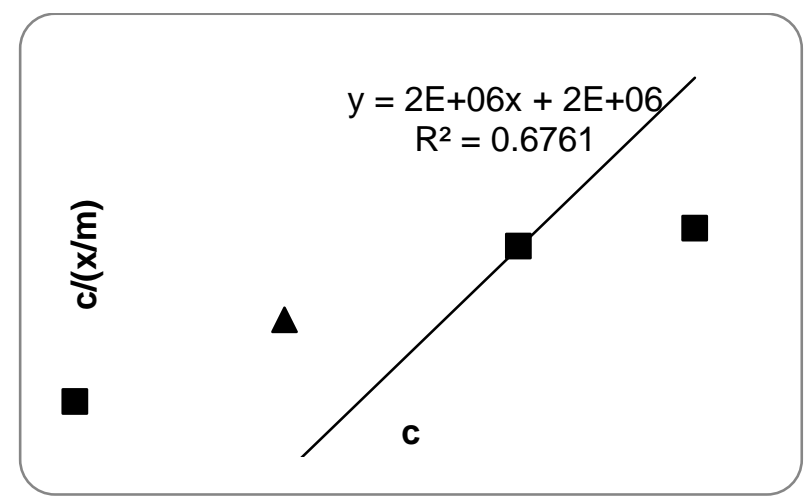

Gambar 6. Isoterm Langmuir adsorpsi zat warna azo jenis Remazol Black B menggunakan membran PEC kitosan-pektin. 
Linieritas kedua tipe isoterm pada adsorpsi zat warna azo jenis Remazol Black $\mathrm{B}$ menunjukkan linieritas yang tinggi, yaitu 95,9 \% untuk isoterm Langmuir dan 98,8 \% untuk isoterm Freundlich. Fakta ini menunjukkan bahwa kedua tipe isoterm terjadi pada proses adsorpsi untuk zat warna azo jenis Remazol Black B. Jika dibandingkan linieritas kedua tipe isoterm tersebut, dapat dilihat ternyata linieritas isoterm adsorpsi tipe Freundlich lebih tinggi dibandingkan isoterm Langmuir. Hasil penelitian ini dikuatkan oleh Anbalagan (2004) yang menyatakan bahwa dengan linieritas 90\%, dapat dinyatakan bahwa kedua tipe isoterm adsorpsi terjadi pada proses adsorpsi zat warna. Namun dengan melihat linieritas kedua tipe isoterm adsorpsi tersebut, ternyata linieritas isoterm
Freundlich lebih tinggi dibandingkan dengan isoterm Langmuir. Oleh karena itu, isoterm adsorpsi zat warna azo jenis Remazol Black B B tipe Freundlich lebih baik digunakan untuk mencirikan mekanisme adsorpsi zat warna azo jenis Remazol Black B. Pendekatan Freundlich mengasumsikan bahwa permukaannya bersifat heterogen, membentuk banyak lapisan, terdapat sisi aktif adsorpsi yang memiliki afinitas tinggi, dan bagian lainnya memiliki afinitas yang rendah.

Untuk daya adsorpsi maksimum ditentukan dari persamaan kurva Langmuir. Persamaan kurva Langmuir yang diperoleh adalah $y=53285 x+3 \times 10^{-7}$, gradient $1 /(\mathrm{x} / \mathrm{m})_{\text {maks }}=53285$ dengan nilai $(\mathrm{x} / \mathrm{m})_{\text {maks }}$ diperoleh $1,88 \times 10^{-5}$ sehingga daya adsorpsi maksimum diperoleh 0,02 mg/g.

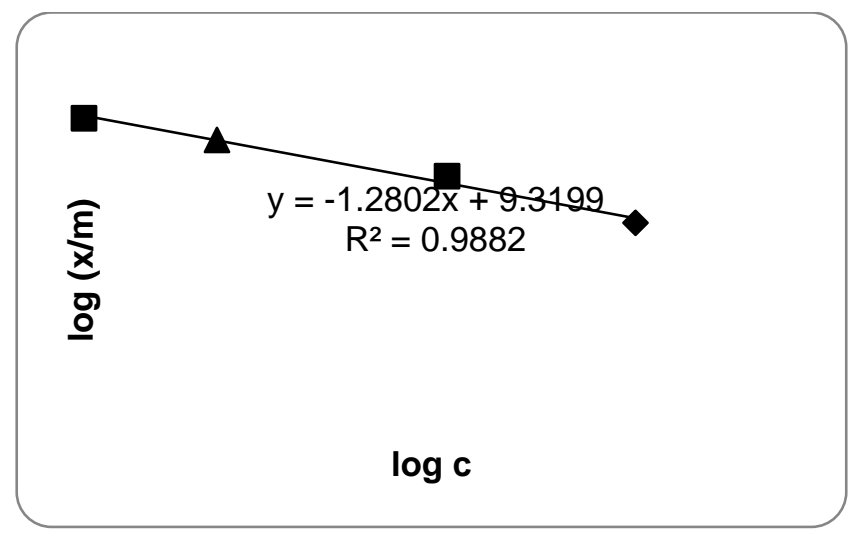

Gambar 7. Isoterm Freundlich adsorpsi zat warna Remazol Black B menggunakan membran PEC kitosan-pektin.

Pada penelitian ini, parameter yang digunakan untuk mengkaji desorpsi zat warna azo jenis Remazol Black B dengan membran PEC kitosan-pektin adalah variasi waktu kontak dengan mempelajari jumlah pelepasan zat warna azo jenis Remazol Black $B$ pada aquabides, $\mathrm{NaCl} 0,1 \mathrm{M}$ dan $\mathrm{NaCl} 1 \mathrm{M}$. Hasil desorpsi disajikan pada Gambar 8. 


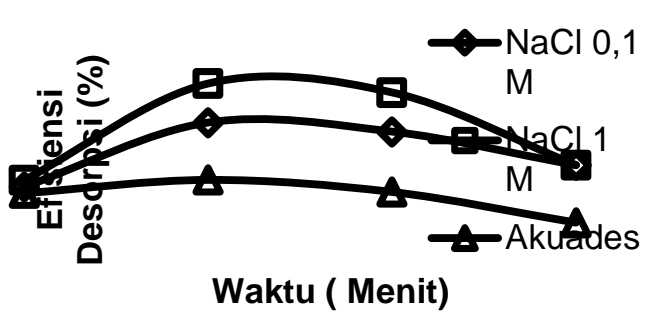

Gambar 8. Efisiensi Desorpsi Zat Warna Azo Jenis Remazol Black B-Membran PEC Kitosan-Pektin

Pada penelitian ini, parameter yang digunakan untuk mengkaji desorpsi zat warna azo jenis Remazol Black $B$ dari membran PEC kitosan-pektin adalah variasi waktu kontak dengan mempelajari jumlah pelepasan zat warna azo jenis Remazol Black $B$ pada akuades, $\mathrm{NaCl} 0,1 \mathrm{M}$ dan $\mathrm{NaCl} 1 \mathrm{M}$. Pemilihan akuades didasarkan pada sifat zat warna azo jenis Remazol Black $B$ yang sangat larut dalam akuades. Untuk pemilihan $\mathrm{NaCl}$ didasarkan pada kekuatan ion dari $\mathrm{NaCl}$, sehingga bisa menggantikan zat warna azo jenis Remazol Black $B$. Keberadaan $\mathrm{NaCl}$ dalam larutan sangat mempengaruhi desorpsi zat warna azo jenis Remazol Black $B$ karena kekuatan ion $\mathrm{Na}^{+}$dari $\mathrm{NaCl}$ akan melepaskan zat warna azo jenis Remazol Black $B$ yang telah berinteraksi dengan membran PEC kitosan pektin. Semakin banyak ion $\mathrm{Na}^{+}$dalam larutan maka semakin banyak jumlah zat warna azo jenis Remazol Black $B$ yang terdesorpsi. Larutan $\mathrm{NaCl} 1 \mathrm{M}$ mampu mendesorpsi zat warna azo jenis Remazol Black $B$ maksimum pada waktu 60 menit sebesar $11,17 \%$ sedangkan larutan $\mathrm{NaCl}$ 0,1 M mendesorpsi sebesar 9,29 \%. Pada waktu 60 menit jumlah zat warna azo jenis
Remazol Black $B$ yang terdesorpsi oleh akuades 6,52 \% lebih kecil dibandingkan dengan jumlah zat warna azo jenis Remazol Black $B$ yang terdesorpsi dengan $\mathrm{NaCl} 0,1$ $\mathrm{M}$ dan $\mathrm{NaCl} 1 \mathrm{M}$. Ion yang terdapat pada akuades tidak cukup kuat untuk mendesorpsi zat warna azo jenis Remazol Black $B$ yang telah terikat pada membran PEC. Faktor kelarutan zat warna azo jenis Remazol Black $B$ dalam akuades tidak mempengaruhi desorpsi zat warna azo jenis Remazol Black $B$. Hal ini mengindikasikan bahwa ikatan antara zat warna azo jenis Remazol Black $B$ dengan membran PEC kitosan pektin mempunyai ikatan yang kuat. Adsorpsi yang terjadi merupakan adsorpsi kimia. komposisi membran PEC sangat mempengaruhi jumlah pelepasan zat warna azo jenis Remazol Black $B$, hal ini berpengaruh terhadap jumlah sisi aktif karboksil yang berikatan lebih kuat dengan membran PEC kitosan pektin.

\section{SIMPULAN}

Berdasarkan hasil penelitian diatas diperoleh kesimpulan sebagai berikut : (1) Efisiensi adsorpsi optimum zat warna azo jenis Remazol Black $B$ menggunakan membran PEC kitosan-pektin menghasilkan $62,75 \%$; (2) Adsorpsi zat warna azo jenis Remazol Black $B$ menggunakan membran PEC kitosan pektin mengikuti pola adsorpsi isoterm Freundlich; (3) Daya adsorpsi maksimum zat warna azo jenis Remazol Black $B$ menggunakan membran PEC kitosan-pektin 0,02 mg/g. (4) Desorpsi zat warna azo jenis Remazol Black $B$ menggunakan membran PEC kitosan-pektin maksimal pada waktu 60 menit pada $\mathrm{NaCl} 1$ M (11,17\%). 


\section{DAFTAR PUSTAKA}

Ayuni, N.P.S. 2013. Studi transpor kreatinin menggunakan membran kompleks polielektrolit (PEC) kitosan-pektin. Tesis (tidak dipublikasikan) Jurusan Kimia. Program Studi Pascasarjana IImu Kimia. Fakultas Matematika dan IImu Pengetahuan Alam. Universitas Gadjah Mada. Yogyakarta.

Asbanu, G. 2013. Studi transpor urea menggunakan membran kompleks polielektrolit (PEC) kitosan-pektin. Tesis (tidak dipublikasikan) Jurusan Kimia. Program Studi Pascasarjana Ilmu Kimia. Fakultas Matematika dan Ilmu Pengetahuan Alam. Universitas Gadjah Mada. Yogyakarta.

Bafana, A., T. Chakrabarti, P. Muthal and G. Kande. 2008.Detoxification of benzidine based azo dyes by E.gallinarum: Time course study. Ecotoxicology andEnvironmental Safety 10: 1-5.

Chen, P., Kuo, T.Y., Kuo, J.R., Tseng, Y.P., Wang, D.M, Lai, J.Y., Hsieh, H.J. 2010. Novel Chitosan-Pectin Composite Membranes with Enhanced Strength, Hydrophilicity and Controllable Disintegration, Carbohydr. Polym. 82, 1236-1242.

Erkurt, H.A. 2010. Biodegradation of Azo Dyes. The Hand Book of Environmental Chemistry. D.Barcelo and A.G. Kostianoy, 9th Ed. Springer: Verlag Berlin Heidelberg (hal. 1-37)

Gong, G.R., Y. Ding., L. Mei, C. Yang, H. Lio and Y. Sun.2005. Utilization of powdered peanut hull asbiosorbent for removal of anionic dyes from aqueoussolution. Dyes and Pigments 64: 187-198.
Guelli. S.M.A., U. Souza., H.L. Brandão and A.A. UlsonDe Souza. 2008. Modeling of liquid pollutantbiodegradation process in a fluidized bed reactor withbiofilm, Sep. Purification Technology 60: 162-173.

Kannan, S., Dhandayuthapani, K and Sutana, M. 2013. Decolorization and Degradation of Azo Dye Remazol Black B By Newly Isolated Pseudomonas putida. Int.J.Curr.Microbiol.App.Sci. 2(4):108-116

Khalid, A. et al. 2011. Decolorization of Remazol Black-B azo dye in soil by fungi. Soil Environ. 30(1). 1-6

Mulder, M., 1991, Basic Principles of Membran Technology, Netherlands, Khewer Academic Publisher.

Nirmasari, A.D, D.S Widodo, A. Haris. tt. Pengaruh $\quad \mathrm{pH} \quad$ Terhadap Elektrodekolorisasi Zat Warna Azo Jenis Remazol Black B dengan Elektroda $\mathrm{PbO}_{2}$. Laboratorium Kimia Analitik. Jurusan Kimia. Fakultas Matematika dan IImu Pengetahuan Alam. Universitas Diponegoro. Semarang

Reisch, M.S. 1996. Asian textile dye makers are a growingpower in changing market. Chemical \& EngineeringNews 15: 10-12.

Shah,M.P., K.A. Patel., S.S Nair., A.M., Darji. 2014. Decolorization of Remazol Black-B by Three Bacterial Isolates. International Journal of Environmental Bioremediation \& Biodegradation. 2 (1). 44-49

Renita, M., Rosdanelli, H., dan Irvan. 2004.Perombakan Zat Warna Azo Reaktif Secara Aerobdan Anaerob, Fakultas Teknik Jurusan Teknik Kimia, Universitas Sumatera Utara

Jurnal Sains dan Teknologi |726 
Tuny, M.T. 2013. Adsorpsi desorpsi metilen biru pada membran kompleks polielektrolit (PEC) kitosan-pektin. Tesis (tidak dipublikasikan) Jurusan Kimia. Program Studi Pascasarjana IImu Kimia. Fakultas Matematika dan Ilmu Pengetahuan Alam. Universitas Gadjah Mada. Yogyakarta. 